\title{
COMPARISON OF TURKEY WITH SOME NEW MEMBERS OF THE EU IN TERMS OF COMPETITIVENESS AND TRADE STRUCTURE
}

\section{Levent Kösekahyaoğlu*}

\section{Abstract:}

Following the accession of ten new members to the European Union (EU) in May 2004, discussions about Turkey's new competitive position with regard to a larger EU became even more prominent in both Europe and Turkey. The main goal of this study is to provide a comparative analysis on macroeconomic performance, trade structure and competitiveness of Turkey and four new members of the EU, namely the Czech Republic, Hungary, Poland and Estonia. We employ Balassa's revealed comparative advantage approach to assess Turkey's competitiveness against the four new members in five commodity groups. Our results suggest that Turkey has a comparative advantage in raw material, labour and partly capital intensive goods against all of the four new members excluding Estonia. However, Turkey appears to have a comparative disadvantage in researchoriented products which require a higher level of technology and investment.

Keywords: Competitiveness, Turkey-EU Trade, Revealed Comparative Advantage.

\section{Özet:}

Dünya ticaretinin artış hızının üretim artışından daha büyük olması, uluslararası rekabetin hizla artmasına ve gerek firma gerekse ülke bazında rekabet gücü tartışmasının giderek daha sık gündemde kalmasına neden olmaktadır Rekabet gücüne ilişkin tartı̧̧malar çok boyutlu bir yapıda gelişirken, çeşitli kurumlar ülkelerin makro ekonomik ve sosyal göstergelerini baz alarak yıllık rekabet gücü stralamaları yayınlamaktadır. Söz konusu stralamalara bakıldığında, Türkiye'nin AB25 içerisindeki başlıca rakiplerinin Çek Cumhuriyeti, Macaristan, Polonya ve Estonya

\footnotetext{
* Assist. Prof. Dr., Süleyman Demirel University.
} 
olduğu görülmektedir. Dolayısıyla, bu çrllşmada Türkiye ile sözü edilen dört $A B$ üyesinin sektörel rekabet güçleri Balassa tarafindan geliştirilen karş̧laş̧tırmalı piyasa payı (relative market share index) ve karşıllaştırmalı ihracat performansı (relative export performance) indeksleri kullanllarak beş farklı mal gurubu için analiz edilmiştir. Çalışmadan elde edilen bulgulara göre, Türkiye Estonya hariç diğer üç ülke karşısında, özellikle hammadde ve işgücü, kısmen de sermaye yoğun malları içeren sektörlerde bir rekabet avantajina sahipken; araştırma bazl mallar olarak tanımlanan ve yüksek teknoloji gerektiren sektörlerde dezavantajl bir konumdadir.

Anahtar Kelimeler: Rekabet gücü, Türkiye-AB dış ticareti, açıklanmış karşılaștırmalı üstünlük.

\section{Introduction}

Following the last enlargement process of the European Union (EU) in May 2004 and the EU's decision towards starting full membership negotiations with Turkey as of October 2005, a comparative analysis of Turkey and the new EU members in terms of their trade structure and competitiveness became an important issue in both parts. It is obvious that a detailed examination of foreign trade performance for Turkey and some of the new members, such as the Czech Republic, Hungary, Poland and Estonia which particularly have similar factor endowments, would provide critical insights on Turkey's recent position in the face of EU.

In order to assess to what extent accession of new ten members would affect Turkey's potential competitiveness against the EU in the future, there is a clear need to compare Turkey's industrial structure with the new members and the key factors behind Turkey's present competitiveness should also be examined carefully. Only after such analysis, one can evaluate actual impact of enlarged EU on Turkish economy.

Given the arguments above, the main aim of this study is to compare Turkey's trade structure and performance with the four new EU members which seem to have similar factor endowments. The work is organised as follows. In section 2, we first present the theoretical arguments on definition and measurement of 'competitiveness' concept and the factors determining countries' ability to compete with each other. A comparison of macroeconomic performance for the five countries under consideration is given in section 3 and we analyse trade structure of these five countries in section 4. Finally, we provide a sectoral analysis on Turkey's 
competitiveness against the four EU members in section 5 by using Balassa's revealed comparative advantage approach. Policy implications of the study on strategic trade policy for Turkey are discussed in conclusion.

\section{Theoretical Assessment on Ccomperative Advantage}

\subsection{Definition and Measurement of Comparative Advantage}

The task of quantifying comparative advantage empirically is not a trivial attempt because the rigor of economic theory imposes severe restrictions and because country and commodity aggregations necessarily entail conceptual compromise. One problem is that the theoretical concept of comparative advantage is usually specified in terms of pre-trade (autarky) relative prices in a distortions world where markets function perfectly. Unfortunately, researchers are confronted with data generated by trade-flows in post-trade equilibria.

Balassa (1965) outlined these difficulties and shortcomings of the classical doctrine in determining comparative advantage and suggested that "revealed comparative advantage" (RCA) can be indicated by the trade performance of individual countries in the sense that the commodity pattern of trade reflects relative costs as well as differences in non-price factors. ${ }^{2}$

Most authors define competitiveness as "an advantage of firms or industries vis-à-vis their competitors in domestic or international markets" (Cockburn et al.1998). Another definition is "to secure a relatively high return on factors of production and relatively high employment levels on a sustainable basis" (European Commission, 1994). A broader definition of competitiveness is the ability to secure and profitably maintain market share (Martin et al. 1991). ${ }^{3}$

${ }^{1}$ Difficulties also arise when applied economists depart from the simplified neoclassical world to incorporate characteristics of the multi-dimensional real world where many commodities flow across national boundaries and where many countries trade the same commodities and have different trading partners.

2 Many applied economists have attempted to approximate comparative advantage using indicators derived from real world post-trade observations. Hillman (1980); Bowen $(1983 ; 1985 ; 1986)$; Ballence et al.(1985;1986); and Yeats (1985) have analysed the properties of various indexes proposed to approximate actual comparative advantage. Ballence et al.(1986) examined the consistency of alternative RCA measures and found considerable incoherence.

${ }^{3}$ See Balassa (1965), Hirsch (1967), and Francis (1989) for different definitions of competitiveness term. 
Given broad definition of the concept, it is not surprising to find out that there is not a unique way to measure competitiveness. There are many ways to obtain an indicator of competitiveness. Among the most widely used competitiveness indicators are relative profits, costs, or prices (Atto 1987). Another way to demonstrate relative competitiveness is to observe revealed competitive advantage through export market shares of pairs of industries in a given market. Following Heidensohn and Hibbert's (1997) suggestion that an analysis of revealed competitive advantage compared to cost or price differences offers a more valid approach for international competitiveness, we employ Balassa's RCA indexes in this work. ${ }^{4}$

\subsection{Determinants of Comparative Advantage}

What factors determine the international competitiveness of a country over another country in a specific industry? There are two alternative approaches on the sources of international competitiveness. On the one hand, competitiveness calls for high sensitivity of exports to costs, therefore, relative costs crucially matter for international competitiveness. On the other hand, relative costs on international trade become less important due to heightened competition on quality differences and more sophisticated products (Carlin et al., 2001). Factors such as the ability of creating and sharing knowledge and turning knowledge into innovations became major determinants to create and sustain competitive advantage (Porter 1990).

Therefore, it is recently argued that the factors determining international trade and competitiveness do not solely depend on price and production cost. The non-price factors, which take into account technology and production scale as well, have recently gained a new dimension.

Regarding the impact of non-price variables on competitiveness, three central findings may be noted. First, research and development (R\&D) and innovation play an important role in many industries, and not only in those that are commonly regarded as high-tech (although the impact is perhaps more pronounced in the latter). Second, in some 'very high-tech' industries

${ }^{4}$ Comparative advantage is distinct from competitiveness because of two reasons. First, competitiveness is related to the relative strength or weakness of a country for producing a given product, while comparative advantage is to the relative strength or weakness of products for a given country. Second, competitiveness is often subject to macroeconomic fluctuations (exchange rate or wage rate), while comparative advantage is structural. See Lafay (1992) for details. 
competitiveness seems to be strongly affected by the size of the domestic market. This is true for aerospace, but may also apply to other industries. Thus, while research and development and innovation may be important for competitiveness in both large and small countries, the latter should be careful not to use the specialization pattern of the former as a kind of yardstick of success. Third, research and development does not only matter for the firm or sector of origin, but spills over to other firms and sectors, and these spillovers are at least as important as the direct effects.

\section{A General Assessment on Competitiveness of Turkey and the New EU Members}

\subsection{Comparison of Macroeconomic Performance}

Table 1 presents the main macroeconomic indicators such as the GDP, the growth rate and the GDP per capita for Turkey and the new EU members over 2000-2004 period. In terms of the GDP in 2004; Turkey has the highest income level of over 300 Billion \$. Poland, the Czech Republic and Hungary appear to have smooth increases in GDP since 2000 and their income levels are relatively higher than the others. Latvia, Estonia and Malta are the countries with an income level below 15 Billion $\$$ and they also have an increasing trend of GDP after 2000.

Regarding the growth level of countries; Latvia $(\% 7,4)$, Lithuania $(\% 7,2)$ and Estonia $(\% 6,4)$ have the highest annual average growth rates over the five years, while Malta, Slovenia, the Czech Republic, Hungary and Poland have a relatively lower average growth around 4 per cent. Although Turkey managed to reach considerably high growth rates of $7,8,6$, and 9 per cent in 2000, 2002, 2003 and 2004, respectively; the 2001 financial crisis had a great negative impact on growth which resulted in 7 per cent drop in GDP. Recently announced 7.6 per cent growth rate of Turkey in 2005 indicates that Turkey succeeded to have consequent positive growth rates over the four years after $2002 .^{5}$

Finally, relatively less populated countries such as Slovenia, Cyprus and Malta, as well as medium size the Czech Republic and Hungary, appear to have the highest GDP per capita levels over $10.000 \$$. Turkey stands as the country with the lowest GDP per capita and even recent income per capita of nearly $5.000 \$$ in 2005 is far below than the other new members.

In sum, Table 1 indicates that the Czech Republic, Hungary and Poland are the countries with comparable GDP levels and that their income levels

${ }^{5}$ See TUIK (2006) for recent figures on GDP and income per capita in Turkey. 
are similar to Turkey. Apart from that, Latvia, Lithuania and Estonia appear to be the fastest growing countries. Partly due to its large population and low productivity, Turkey has the lowest income per capita despite the high growth rates obtained after 2002 .

Table 1: Comparison of Macroeconomic Performance, 2000-2004

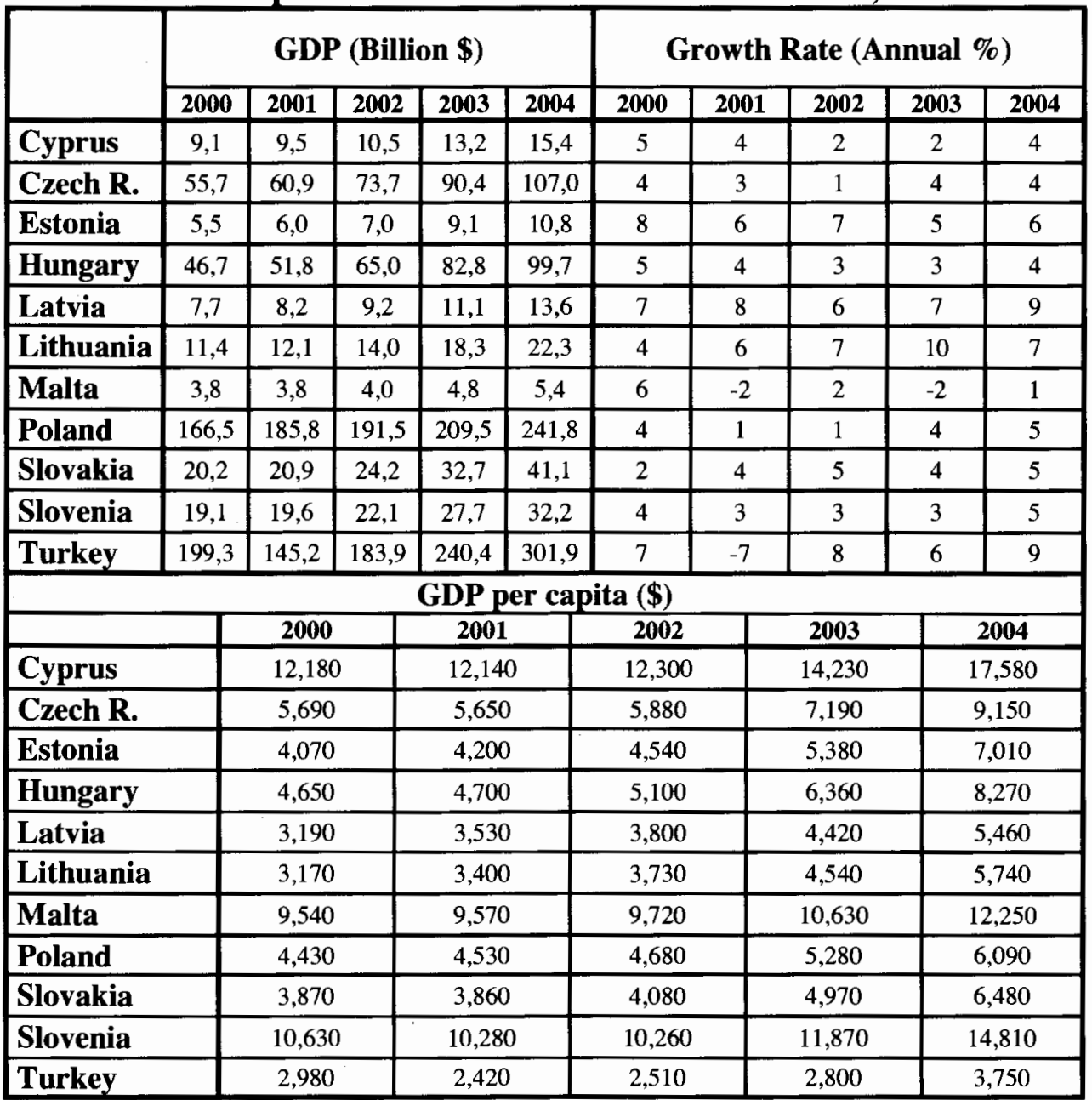

Source: World Bank (2005), World Development Indicators Database.

\subsection{Overall Comparison of Competitiveness}

International Institute for Management Development (IMD) and World Economic Forum (WEF) are the two main institutions measuring the overall competitiveness of countries. On the one hand, WEF attempts at predicting potential growth performance of countries with in 5-10 years in 
Growth Competitiveness Index (GCI). On the other hand, IMD publishes a more detailed and respected annual report called World Competitiveness Yearbook in which competitiveness of countries are assessed by 8 main and 250 sub criteria. Some of these criteria are countable, such as the size of GDP, the number of patents and the inflation rate while some are noncountable, such as the level of education, the motivation of individuals and the institutional framework.

Table 2: Comparison of Overall Competitiveness

\begin{tabular}{|l|c|c|c|}
\hline & $\begin{array}{c}\text { IMD 2005 } \\
\text { Competitiveness } \\
\text { Score* }\end{array}$ & $\begin{array}{c}\text { IMD 2005 } \\
\text { Competitiveness } \\
\text { Ranking }\end{array}$ & $\begin{array}{c}\text { IMD 2004 } \\
\text { Competitiveness } \\
\text { Ranking }\end{array}$ \\
\hline Estonia & 66,7 & 26 & 28 \\
\hline $\begin{array}{l}\text { Czech } \\
\text { Republic }\end{array}$ & 60,1 & 36 & 43 \\
\hline Hungary & 59,8 & 37 & 42 \\
\hline Turkey & 51,2 & 48 & 55 \\
\hline Poland & 39,0 & 57 & 57 \\
\hline
\end{tabular}

Source: International Institute for Management Development -IMD- (2005), The World Competitiveness Scoreboard 2005. * Country scores, out of 100.

In Table 2, we present the competitiveness scores and rankings of Estonia, the Czech Republic, Hungary, Poland and Turkey according to the IMD competitiveness report. It is clear from Table 2 that among the five countries we consider Estonia is the most competitive country with the highest ranking in both 2004 and 2005. However, Poland has the lowest compotitiveness score and ranking in both years. Turkey's competitiveness score in 2005 is 51,2 out of 100 and its ranking went up from 55 in 2004 to 48 in 2005 . We can also conclude that all of five countries but Poland managed increase their overall competitiveness ranking in 2005.

\section{Analysis on Trade Structure}

\subsection{Comparison of Total Trade}

Trend of exports and imports during 1993-2004 period in the five countries we examine is given in Table 3 . In examining the changes in trade flows over this time period, the 1996 Customs Union (CU) Agreement between Turkey and the EU and the free trade agreements signed between the EU and the new members should be particularly taken into 
consideration. Because due to these agreements the trade restrictions and the tariffs have been reduced significantly in the countries under consideration. ${ }^{6}$

The following conclusions can be drawn from Table 3;

- All countries experienced substantial increases in their exports. The size of change in exports was 4,1 times in Turkey; 4,5 times in Estonia; 4,7 times in the Czech Republic; 5,3 times in Poland and 6,1 times in Hungary and between 1993 and 2004. Therefore, it seems that Hungary performed best in boosting exports while Turkey had the lowest rate of increase.

Table 3: Comparison of Total Exports and Imports, (Million \$)

\begin{tabular}{|c|c|c|c|c|c|c|c|c|c|c|}
\hline & \multicolumn{2}{|c|}{ Turkey } & \multicolumn{2}{c|}{ Czech Republic } & \multicolumn{2}{c|}{ Hungary } & \multicolumn{2}{c|}{ Poland } & \multicolumn{2}{c|}{ Estonia } \\
\cline { 2 - 11 } & Exports & Imports & Exports & Imports & Exports & Imports & Exports & Imports & Exports & Imports \\
\hline 1993 & 15,343 & 29,174 & 14,465 & 14,615 & 8,905 & 12,530 & 14,140 & 20,180 & - & - \\
\hline 1994 & 18,106 & 23,270 & 15,940 & 17,310 & 10,700 & 14,555 & 17,240 & 22,680 & 1,303 & 1,654 \\
\hline 1995 & 21,637 & 35,709 & 21,335 & 25,085 & 12,865 & 15,465 & 22,895 & 29,050 & 1,840 & 2,546 \\
\hline 1996 & 23,224 & 43,627 & 22,165 & 27,800 & 15,705 & 18,145 & 24,440 & 37,135 & 2,078 & 3,224 \\
\hline 1997 & 26,261 & 48,559 & 22,360 & 27,105 & 19,100 & 21,235 & 25,750 & 42,310 & 2,936 & 4,437 \\
\hline 1998 & 26,974 & 45,921 & 25,855 & 28,340 & 23,005 & 25,705 & 28,230 & 47,055 & 3,245 & 4,787 \\
\hline 1999 & 26,588 & 40,671 & 26,241 & 28,151 & 25,012 & 28,008 & 27,397 & 45,903 & 3,017 & 4,109 \\
\hline 2000 & 27,775 & 54,503 & 28,996 & 32,174 & 28,016 & 31,955 & 31,651 & 48,940 & 3,830 & 5,052 \\
\hline 2001 & 31,334 & 41,399 & 33,324 & 36,297 & 30,436 & 33,617 & 35,998 & 50,184 & 4,015 & 5,230 \\
\hline 2002 & 36,059 & 51,554 & 38,492 & 40,656 & 34,517 & 37,755 & 41,133 & 55,299 & 4,336 & 5,863 \\
\hline 2003 & 47,253 & 69,340 & 48,702 & 51,728 & 43,094 & 47,808 & 53,762 & 68,272 & 5,597 & 7,930 \\
\hline 2004 & 63,121 & 97,540 & 68,657 & 69,510 & 54,857 & 59,332 & 74,854 & 89,174 & 5,945 & 8,728 \\
\hline
\end{tabular}

Source: World Trade Organization (2005), International Trade Statistics.

Similar with the size of GDP, the Czech Republic, Hungary, Poland and Turkey have a comparable trade potential in terms of the volume of their exports while Estonia clearly has a significantly lower capacity of trade flows.

Although their export capacity is lower than the others, Hungary and Estonia managed to raise their exports as much as five times between 1993 and 2004.

Regarding development of imports in the countries we examine, the following remarks can be made;

${ }^{6}$ For a analysis of foreign trade performance of the Czech Republic, Hungary and Poland, see Jakab et al. (2001). Nilsson (2000) examines to what extend the new members have accomplished trade integration with the EU by Gravity model. For a study of foreign trade, competitiveness and growth potential of the new members, see Lankhuizen (2000). 
All countries experienced a smooth upward trend in their imports. The magnitude of change in imports was 3,3 times in Turkey; 4,4 times in Poland; 4,7 times in the Czech Republic and Hungary and 5,4 times in Estonia between 1993 and 2004. Thus, the highest rise in imports was in Estonia and Turkey had the lowest rate of increase as in the case of exports.

- Due to the drastic fluctuations in income level, imports in Turkey followed a rather instable path. These sharp movements in imports were particularly noticeable over periods of the 1994 and 2001 currency crisis and the 1999 Marmara earthquake.

- Although imports have grown faster than exports in some cases, all countires appear to be confronted by a gradually escalating trade deficit problem.

Table 3 also reveals some important facts about impact of the CU Agreement on Turkey's foreign trade. It can be seen from Table 3 that there was no clear upward shift in Turkey's imports after implementation of the agreement in 1996. Soğuk and Uyanusta (2004:11-14) and Yetkin (1998:8990) argue that since the EU has already removed all tariffs on industrial goods imported from Turkey unilaterally in 1971 there was no major increase in Turkey's exports to the EU as a result of the CU agreement.

\subsection{Comparison of Trade with the $E U$}

In order to assess the structure of trade with the EU for each country, the size of trade flows with the EU, the share five country in EU's external trade, the ranking of each country in Turkey's external and finally the share of trade with EU in total trade are given in Table 4-6. In terms of EU's exports to the five countries under consideration, Table 4 indicates that Turkey was the largest market for the EU goods with an export potential of about 8 Billion $€$ in 1990, however, Poland became the best market for the EU's exports which reached as much as 54 Billion $€$ in 2004. Although EU's exports to Turkey amounted to 38 Billion $€$ in 2004, Turkey became the third biggest market for the EU, after Poland and the Czech Republic. Share of each country in EU's total external exports has also increased between 1990 and 2003, reaching 3,9 per cent for Poland, 3,1 per cent for the Czech Republic and 2,8 per cent for Turkey. As a result of all these expansion in EU's exports, Poland, the Czech Republic and Turkey became the most important markets for the EU and the ranking of these tree countries increased between 1990 and 2003. However, Turkey was the 8th largest market for EU's exports in both 1990 and 2003. 
Table 4: Trade with the EU: Exports (Billion $€$ )

\begin{tabular}{|l|c|c|c|c|c|c|c|c|c|c|c|c|c|}
\hline & \multicolumn{9}{|c|}{ EU's Exports to } & \multicolumn{5}{|c|}{ External EU Exports } \\
\cline { 2 - 16 } & $\mathbf{1 9 9 0}$ & $\mathbf{1 9 9 5}$ & $\mathbf{1 9 9 9}$ & $\mathbf{2 0 0 0}$ & $\mathbf{2 0 0 1}$ & $\mathbf{2 0 0 2}$ & $\mathbf{2 0 0 3}$ & $\mathbf{2 0 0 4}$ & $\mathbf{1 9 9 0}$ & $\mathbf{2 0 0 0}$ & $\mathbf{2 0 0 3}$ & $\mathbf{1 9 9 0}$ & $\mathbf{2 0 0 3}$ \\
\hline Poland & 4,4 & 15,3 & 30,9 & 36,4 & $\mathbf{3 8 , 8}$ & 40,5 & 41,7 & 54,0 & 1,2 & 3,5 & 3,9 & 19 & 5 \\
\hline Czech R. & 2,6 & 11,6 & 20,4 & 26,0 & 30,1 & 31,1 & 32,5 & 44,5 & 0,7 & 2,5 & 3,1 & 31 & 7 \\
\hline Hungary & 2,8 & 8,7 & 18,6 & 22,6 & 24,3 & 25,4 & 26,7 & 32,6 & 0,8 & 2,4 & 2,6 & 28 & 9 \\
\hline Estonia & - & 1,3 & 2,4 & 3,3 & 3,2 & 3,5 & 3,7 & 5,0 & - & 0,3 & 0,3 & - & 40 \\
\hline Turkey & 7,7 & 13,4 & 20,9 & 30,7 & 20,9 & 25,4 & 29,4 & 38,0 & 2,1 & 3,1 & 2,8 & 8 & 8 \\
\hline
\end{tabular}

Source: European Commission (2004) and (2005), External and Intra-European Union Trade Statistical Yearbook.

As for EU's imports, Table 5 shows that Turkey was the largest supplier for the EU with a trade of almost 6 Billion $€$ in 1990, however, both Poland and the Czech Republic managed to have higher trade potential, reaching 47,5 Billion $€$ in 2004. EU's imports from Poland and Hungary went up 9,3 and 12,2 times between 1990 and 2004, respectively. EU's imports from the Czech Republic increased even more dramatically, as much as 18,2 times, over the same period while the change in imports from Turkey was only 5,2 times.

Table 5: Trade with the EU: Imports (Billion $\theta$

\begin{tabular}{|l|c|c|c|c|c|c|c|c|c|c|c|c|c|}
\hline & \multicolumn{9}{|c|}{ EU's Imports from } & \multicolumn{4}{c|}{ External EU Imports } \\
\hline & \multicolumn{9}{|c|}{} & \multicolumn{3}{c|}{ Share (\%) } & \multicolumn{3}{c|}{ Ranking } \\
\cline { 2 - 18 } & $\mathbf{1 9 9 0}$ & $\mathbf{1 9 9 5}$ & $\mathbf{1 9 9 9}$ & $\mathbf{2 0 0 0}$ & $\mathbf{2 0 0 1}$ & $\mathbf{2 0 0 2}$ & $\mathbf{2 0 0 3}$ & $\mathbf{2 0 0 4}$ & $\mathbf{1 9 9 0}$ & $\mathbf{2 0 0 0}$ & $\mathbf{2 0 0 3}$ & $\mathbf{1 9 9 0}$ & $\mathbf{2 0 0 3}$ \\
\hline Poland & 5,1 & 12,2 & 20,8 & 27,6 & $\mathbf{3 2 , 3}$ & 34,9 & 38,4 & 47,5 & 1,2 & 2,2 & 3,1 & 18 & 7 \\
\hline Czech R. & 2,6 & 8,9 & 21,6 & 26,8 & 31,8 & 34,5 & 37,2 & 47,5 & 0,6 & 2,0 & 3,0 & 31 & 8 \\
\hline Hungary & 2,9 & 7,6 & 19,3 & 24,8 & 27,5 & 29,9 & 30,9 & 35,5 & 0,7 & 2,1 & 2,6 & 29 & 9 \\
\hline Estonia & - & 889 & 1,9 & 3,0 & 3,0 & 3,0 & 3,3 & 3,9 & - & 0,3 & 0,3 & - & 45 \\
\hline Turkey & 5,9 & 9,2 & 15,6 & 18,2 & 21,4 & 23,6 & 25,9 & 30,9 & 1,4 & 1,6 & 2,4 & 14 & 10 \\
\hline
\end{tabular}

Source: European Commission (2004) and (2005), External and Intra-European Union Trade Statistical Yearbook.

In addition to the EU's trade (exports and imports) with the countries under consideration, we examine the share of EU in each country's total trade during 1999-2004 period in Table 6. 
Table 6: Share of EU in Total Trade, \%

\begin{tabular}{|c|c|c|c|c|c|c|c|c|c|c|}
\hline & \multicolumn{2}{|c|}{ CZECH REP. } & \multicolumn{2}{|c|}{ HUNGARY } & \multicolumn{2}{|c|}{ POLAND } & \multicolumn{2}{|c|}{ ESTONIA } & \multicolumn{2}{|c|}{ TURKEY } \\
\hline & $\begin{array}{c}\text { Share of } \\
\text { exports } \\
\text { to EU } \\
\%\end{array}$ & $\begin{array}{c}\text { Share of } \\
\text { imports } \\
\text { from EU } \\
\%\end{array}$ & $\begin{array}{c}\text { Share of } \\
\text { exports } \\
\text { to EU } \\
\%\end{array}$ & $\begin{array}{c}\text { Share of } \\
\text { imports } \\
\text { from EU } \\
\%\end{array}$ & $\begin{array}{c}\text { Share of } \\
\text { exports } \\
\text { to EU } \\
\%\end{array}$ & $\begin{array}{c}\text { Share of } \\
\text { imports } \\
\text { from EU } \\
\%\end{array}$ & \begin{tabular}{|c|} 
Share of \\
exports \\
to EU \\
$\%$
\end{tabular} & $\begin{array}{c}\text { Share of } \\
\text { imports } \\
\text { from EU } \\
\%\end{array}$ & $\begin{array}{c}\text { Share of } \\
\text { exports } \\
\text { to EU } \\
\%\end{array}$ & $\begin{array}{c}\text { Share of } \\
\text { imports } \\
\text { from EU } \\
\%\end{array}$ \\
\hline 99 & 86,7 & 76,4 & 82,1 & 70,7 & 80,9 & 71,6 & 82,6 & 75,0 & 56,1 & 53,7 \\
\hline & 85,0 & 75,1 & 81,3 & 64,9 & 80,2 & 68,5 & 88,2 & 71,7 & 54,2 & 50,2 \\
\hline 01 & 85,4 & 74,3 & 80,8 & 64,8 & 80,3 & 69,2 & 81,0 & 66,6 & 53,7 & 45,8 \\
\hline 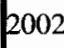 & 84,7 & 72,3 & 81,9 & 63,6 & 80,2 & 69,2 & 83,3 & 68,6 & 53,9 & 47,4 \\
\hline 03 & 86,3 & 71,1 & 81,1 & 63,1 & 80,8 & 69,0 & 82,5 & 64,9 & 55,0 & 48,1 \\
\hline 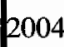 & 86,0 & 79,6 & 79,4 & 66,9 & 78,7 & 74,7 & 81,2 & 74,6 & 54,8 & 46,7 \\
\hline
\end{tabular}

Source: Calculated from European Commission (2005), External and Intra-European Union Trade.

The following comments can be made from Table 6 :

The share of exports to the EU is almost 80 percent for Hungary, Poland and Estonia and it even reaches 86 percent for the Czech Republic in 2004. Given this excessive share of EU in total trade, it is clear that all of four new members have established closer ties and trade partnership with the EU during their transition and negotiation periods for full membership.

- The share of imports from the EU also constitutes a major part of total imports for the new members, however, the share of imports is less than that of exports for all countries.

- The share exports to the EU constitutes more than half of Turkey's total exports, therefore, the EU appears to be a stable and important market for Turkey. Almost half of Turkey's imports are from the EU and the share of EU in Turkey's total imports has been going down since 1999.

The picture we present in Table 4-6 shows that both the new members and Turkey entered a new period of increase in total trade and a rise in the share of trade with the EU after implementing free trade agreements. This result is not surprising at all and is called 'trade creation effect' in economic integration theory.

\section{Analysis on Revealed Comparative Advantage}

Although there are many methods to assess international competitiveness of countries, Balassa's 'revealed comparative advantage' 
(RCA) index is the most commonly used measure. ${ }^{7}$ Balassa's RCA index is easily computable as it is only based on export and import values of countries. Many studies employed RCA method to evaluate competitiveness of Turkey with regard to comparable EU countries, such as Greece, Portugal, Spain and some of new members. ${ }^{8}$

We first examine competitiveness of the countries under consideration by using Balassa's RCA index (relative export-import measure) in the five product categories developed by Hufbauer and Chilas (1974). These categories are defined as; raw material-intensive goods, labour-intensive goods, capital- intensive goods, easily imitable-research oriented goods and difficultly imitable research-oriented goods. ${ }^{9}$ Secondly, in order to examine competitiveness at sectoral level, we compare Turkey with the other four countries by using the relative market share analysis of Balassa.

\subsection{Comparative Advantage Estimated by Relative Export-Import Measure}

In measuring competitiveness of countries, it is argued that using not only exports but also imports data would be more appropriate as 'competitiveness' is a net trade concept (Bowen, 1983: 464-472). The most commonly used competitiveness measure including both exports and imports data is comparative export performance index. This index is given in equation (1);

$$
\operatorname{CEP}_{\mathrm{ij}}=\left(\mathbf{X}_{\mathrm{ij}} / \mathbf{X}_{\mathrm{it}}\right) /\left(\mathbf{M}_{\mathrm{ij}} / \mathbf{M}_{\mathrm{it}}\right)
$$

where $\mathrm{CEP}_{\mathrm{ij}}$ denotes the revealed comparative advantage index of country $i$ in commodity $j ; X_{\mathrm{ij}}$ and $\mathrm{M}_{\mathrm{ij}}$ are exports and imports of country $i$ in commodity $j ; X_{i t}$ and $\mathrm{M}_{\mathrm{it}}$ are total exports and total imports of country

${ }^{7}$ See Hillman $(1980)$, Bowen $(1983 ; 1985 ; 1986)$, Ballence et al . $(1985 ; 1986)$ and Yeats (1985) for the other methods and measures used in examination of international competitiveness. Balassa's RCA index has been used in the following studies; Lafay (1992), Lee (1995), Rodas-Martini (1998), Yue and Hua (2002), Wu and Chen (2004).

${ }^{8}$ For recent studies, see Kucukahmetoglu (1996), Akgungor et al. (2002), Karakaya and Ozgen (2002), Yilmaz (2002; 2003), Yilmaz and Ergun (2003), Ferman et al. (2004).

${ }^{9}$ See Appendix Table 1 for SITC categorization of goods given by Hufbauer and Chilas (1974). 
$i$. The higher (lower) the CEP index, the more (less) and successful is the trade performance of the country in question in a particular area of industry.Table 7 shows the comparative export performance of each country in the five industry groups classified by Hufbauer and Chilas (1974) over the period between 1993 and 2004. The following conclusions can be drawn from Table 7.

- Turkey's export performance decreased constantly over time not only in raw material-intensive goods (group A) but also in traditional export industries of labour-intensive goods (group B) in which Turkey has the highest comparative advantage. Export performance of Turkey in capitalintensive goods (group C) followed an unsteady trend reaching its highest values in 2001 and 2002. Turkey appears to have a rather low export performance in both easily imitable-research oriented goods (group D) and difficultly imitable research-oriented goods (group E). However, Turkey's comparative advantage in these commodity groups increased noticeably particularly after the $2000 \mathrm{~s}^{10}$

- Export performance of the Czech Republic diminished slowly in commodity groups $\mathrm{A}, \mathrm{B}$ and $\mathrm{D}$, while there has been a regular increase in groups $\mathrm{D}$ and $\mathrm{E}$ indicating the high trade performance and comparative advantage of this country in high-tech goods. Compared to other four, the Czech Republic has the highest comparative export performance index value in difficultly imitable research-oriented goods (group E).

Table 7: Comparative Export Performance (CEP)*

\begin{tabular}{|c|c|c|c|c|c|c|c|c|c|c|c|c|c|c|c|}
\hline & \multicolumn{4}{|c|}{ TURKEY } & \multicolumn{4}{|c|}{ CZECH REPUBLIC } & \multicolumn{6}{c|}{ HUNGARY } \\
\cline { 2 - 17 } & $\mathbf{A}$ & $\mathbf{B}$ & $\mathbf{C}$ & $\mathbf{D}$ & $\mathbf{E}$ & $\mathbf{A}$ & $\mathbf{B}$ & $\mathbf{C}$ & $\mathbf{D}$ & $\mathbf{E}$ & $\mathbf{A}$ & $\mathbf{B}$ & $\mathbf{C}$ & $\mathbf{D}$ & $\mathbf{E}$ \\
\hline $\mathbf{1 9 9 3}$ & 0,91 & 3,65 & 1,05 & 0,33 & 0,19 & 0,83 & 1,66 & 1,57 & 0,41 & 0,68 & 1,18 & 1,16 & 0,99 & 0,64 & 0,91 \\
\hline $\mathbf{1 9 9 4}$ & 0,82 & 3,27 & 1,33 & 0,28 & 0,23 & 0,81 & 1,73 & 1,37 & 0,43 & 0,70 & 1,18 & 1,12 & 0,86 & 0,63 & 0,90 \\
\hline $\mathbf{1 9 9 5}$ & 0,79 & 3,26 & $\mathbf{1 , 1 9}$ & 0,27 & 0,25 & 0,82 & 1,49 & 1,22 & 0,49 & 0,84 & 1,26 & 1,03 & 0,97 & 0,70 & 0,97 \\
\hline $\mathbf{1 9 9 6}$ & 0,76 & 3,32 & 1,21 & 0,30 & 0,26 & 0,76 & 1,54 & 1,24 & 0,48 & 0,87 & 1,12 & 1,15 & 0,92 & 0,60 & 1,06 \\
\hline $\mathbf{1 9 9 7}$ & 0,86 & 3,20 & 0,97 & 0,34 & 0,28 & 0,66 & 1,41 & 1,30 & 0,50 & 0,94 & 1,09 & 0,96 & 0,86 & 1,06 & 0,97 \\
\hline $\mathbf{1 9 9 8}$ & 0,93 & 3,08 & 0,88 & 0,39 & 0,30 & 0,65 & 1,34 & 1,34 & 0,50 & 0,93 & 1,16 & 0,91 & 0,78 & 1,26 & 0,99 \\
\hline $\mathbf{1 9 9 9}$ & 0,75 & $\mathbf{3} 16$ & 1,06 & 0,30 & 0,41 & 0,65 & 1,34 & 1,37 & 0,45 & 0,93 & 1,08 & 0,90 & 0,87 & 1,31 & 0,92 \\
\hline $\mathbf{2 0 0 0}$ & 0,56 & 3,43 & 0,93 & 0,38 & 0,50 & 0,55 & 1,38 & 1,41 & 0,55 & 0,94 & 1,13 & 0,90 & 0,92 & 1,47 & 0,87 \\
\hline $\mathbf{2 0 0 1}$ & 0,54 & 3,01 & 1,46 & 0,41 & 0,48 & 0,91 & 1,35 & 1,40 & 0,72 & 0,89 & 1,09 & 0,97 & 0,93 & 1,41 & 0,86 \\
\hline $\mathbf{2 0 0 2}$ & 0,49 & 2,97 & 1,53 & 0,51 & 0,42 & 0,52 & 1,23 & 1,36 & 0,84 & 0,90 & 0,82 & 0,95 & 0,89 & 1,50 & 0,87 \\
\hline $\mathbf{2 0 0 3}$ & 0,49 & 3,12 & 1,29 & 0,50 & 0,49 & 0,42 & 1,23 & 1,33 & 0,85 & 0,92 & 0,98 & 0,83 & 0,81 & 1,61 & 0,89 \\
\hline $\mathbf{2 0 0 4}$ & 0,52 & 3,02 & 1,30 & 0,55 & 0,47 & 0,54 & 1,16 & 1,25 & 0,90 & 0,97 & 0,95 & 0,91 & 0,87 & 1,52 & 0,87 \\
\hline
\end{tabular}

${ }^{10}$ Foreign direct investment in industries of transportation equipment by companies such as Ford, Toyata and Hyundai may be one of the reasons behind Turkey's success in exports of goods classified in groups $\mathrm{D}$ and $\mathrm{E}$. 
Table 7: (continues)

\begin{tabular}{|c|c|c|c|c|c|c|c|c|c|c|}
\hline & \multicolumn{9}{|c|}{ POLAND } & \multicolumn{5}{|c|}{ ESTONIA } \\
\cline { 2 - 11 } & $\mathbf{A}$ & $\mathbf{B}$ & $\mathbf{C}$ & $\mathbf{D}$ & $\mathbf{E}$ & $\mathbf{A}$ & $\mathbf{B}$ & $\mathbf{C}$ & $\mathbf{D}$ & $\mathbf{E}$ \\
\hline $\mathbf{1 9 9 3}$ & 0,95 & 1,42 & 1,59 & 0,34 & 0,75 & 0,88 & 1,30 & 0,70 & 0,82 & 0,53 \\
\hline $\mathbf{1 9 9 4}$ & 1,00 & 1,40 & 1,64 & 0,34 & 0,68 & 0,90 & 1,30 & 0,66 & 0,89 & 0,52 \\
\hline $\mathbf{1 9 9 5}$ & 1,02 & 1,48 & 1,40 & 0,37 & 0,70 & 0,90 & 1,22 & 0,75 & 0,76 & 0,51 \\
\hline $\mathbf{1 9 9 6}$ & 0,95 & 1,62 & 1,22 & 0,40 & 0,73 & 0,85 & 1,37 & 0,70 & 0,79 & 0,55 \\
\hline $\mathbf{1 9 9 7}$ & 1,13 & 1,65 & 1,16 & 0,45 & 0,58 & 0,94 & 1,31 & 0,60 & 1,06 & 0,50 \\
\hline $\mathbf{1 9 9 8}$ & 1,16 & 1,61 & 1,03 & 0,44 & 0,75 & 0,87 & 1,35 & 0,53 & 1,27 & 0,46 \\
\hline $\mathbf{1 9 9 9}$ & 1,04 & 1,65 & 1,05 & 0,39 & 0,78 & 0,77 & 1,40 & 0,59 & 1,21 & 0,40 \\
\hline $\mathbf{2 0 0 0}$ & 0,80 & 1,63 & 1,25 & 0,41 & 0,89 & 0,71 & 1,31 & 0,59 & 1,92 & 0,33 \\
\hline $\mathbf{2 0 0 1}$ & 0,81 & 1,59 & 1,15 & 0,42 & 0,96 & 0,82 & 1,40 & 0,52 & 1,33 & 0,46 \\
\hline $\mathbf{2 0 0 2}$ & 0,84 & 1,56 & 1,08 & 0,46 & 0,97 & 0,90 & 1,52 & 0,57 & 1,26 & 0,45 \\
\hline $\mathbf{2 0 0 3}$ & 0,84 & 1,59 & 1,04 & 0,45 & 0,97 & 0,84 & 1,67 & $\mathbf{0 , 6 5}$ & 1,24 & 0,45 \\
\hline $\mathbf{2 0 0 4}$ & 0,89 & 1,52 & 1,20 & 0,46 & 0,89 & 0,69 & 1,57 & 0,55 & 1,59 & 0,49 \\
\hline
\end{tabular}

Source: Calculated from United Nations Statisties Division- (COMTRADE), SITC. Rev-3 data.

*A: Raw material-intensive goods, B: Labour-intensive goods, C: Capitalintensive goods, D: Easily imitable-research oriented goods, E: Difficultly imitable research-oriented goods. (See Appendix Table 1 for definition of each group)

Similar to the Czech Republic, export performance of Hungary in groups $\mathrm{A}, \mathrm{B}$ and $\mathrm{C}$ fell down noticeably while there was an upward trend in group D. Hungary appears to able to keep its high export performance in difficultly imitable research-oriented goods (group E) since 1993.

Poland has a flowing trend in groups $A, E$ and particularly $B$ in which the country has the highest export performance and competitiveness. Similar to Turkey, Poland has a relatively low export performance in group D.

Having the highest ranking in IMD's competitiveness list, Estonia's export performance in group D has been predominantly high since 1993. However, similar to Turkey, its competitiveness in group $\mathrm{E}$ is rather low.

\section{Index \\ 4.2. Comparative Advantage Estimated by Relative Market Share}

Many measures of competitiveness have been derived from Balassa's $\mathrm{RCA}$ index. One of these approaches is relative market share index which enables us to compare two countries' competitiveness in a particular industry (Heidensohn and Hibbert, 1997: 27). This measure is defined as follows (Akgüngör et al.: 2002:41-42);

$$
\mathbf{R C A}_{\mathrm{irj}}=\ln \left[\left(\mathbf{X}_{\mathbf{i}, \mathrm{j}}\right) /\left(\boldsymbol{\Sigma} \mathbf{X}_{\mathrm{i}, \mathrm{t}}\right) /\left[\left(\mathbf{X}_{\mathbf{r}, \mathrm{j}}\right) /\left(\boldsymbol{\Sigma} \mathbf{X}_{\mathrm{r}, \mathrm{t}}\right)\right]\right]
$$

where $\mathrm{RCA}_{\mathrm{irj}}$ shows revealed comparative advantage index of country $i$ (Turkey) versus rival $(r)$ country in commodity $j ;\left(\mathrm{X}_{\mathrm{i}, \mathrm{j}}\right)$ is exports of country $i$ in commodity $j ;\left(\mathrm{X}_{\mathrm{r}, \mathrm{j}}\right)$ is exports of country $r$ in commodity $j ;\left(\Sigma \mathrm{X}_{\mathrm{i}, \mathrm{t}}\right)$ and $\left(\Sigma \mathrm{X}_{\mathrm{r}, \mathrm{t}}\right)$ are total exports of country $i$ and $r$, respectively. 
RCA index equation (2) allows us to compare two or more countries' comparative advantage in their trade with a certain region. A positive (negative) value of RCA means that Turkey has a high (low) comparative advantage against the rival EU country (Ferman et al., 2004: 9). Table 8 presents Turkey's comparative advantage against the Czech Republic, Hungary, Poland and Estonia in the five commodity groups.

The following remarks can be made from Table 8;

- Regarding Turkey's competitiveness against the Czech Republic, Turkey appears to have comparative advantage in groups A and B with an unstable trend. In other groups, the Czech Republic seems to be more competitive, with the only exception of group C in 2004.

- In the case of Turkey and Hungary, Turkey has an advantage in groups B and C as well as group A since 1997. Hungary seems to be more competitive in groups $\mathrm{D}$ and $\mathrm{E}$.

Turkey seems to have a noticeable comparative advantage against Poland in group B, while the opposite holds in groups A, D, and E. We have ambiguous results for group $\mathrm{C}$.

Table 8: RCA of Turkey against the Czech Republic, Hungary, Poland and Estonia *

\begin{tabular}{|c|c|c|c|c|c|c|c|c|c|c|}
\hline & \multicolumn{5}{|c|}{ TURKEY*CZECH REPUBLIC } & \multicolumn{5}{|c|}{ TURKEY *HUNGARY } \\
\hline & $\mathbf{A}$ & $\mathbf{B}$ & $\mathbf{C}$ & D & $\mathbf{E}$ & $\mathbf{A}$ & $\mathbf{B}$ & $\mathbf{C}$ & $\mathbf{D}$ & $\mathbf{E}$ \\
\hline 1993 & 0,241 & 0,441 & $-0,214$ & $-0,635$ & $-1,084$ & $-0,146$ & 0,534 & 0,201 & $-1,097$ & $-1,106$ \\
\hline 1994 & 0,299 & 0,351 & $-0,154$ & $-0,731$ & $-0,950$ & $-0,041$ & 0,594 & 0,348 & $-1,030$ & $-0,990$ \\
\hline 1995 & 0,426 & 0,431 & $-0,164$ & $-0,746$ & $-1,169$ & $-0,171$ & $0,6 \overline{65}$ & 0,136 & $-1,196$ & $-1,099$ \\
\hline 1996 & 0,409 & 0,393 & $-0,128$ & $-0,723$ & $-1,088$ & $-0,173$ & 0,548 & 0,236 & $-0,991$ & $-1,040$ \\
\hline 1997 & 0,571 & 0,472 & $-0,295$ & $-0,580$ & $-1,096$ & 0,158 & 0,867 & 0,382 & $-1,606$ & $-1,130$ \\
\hline 1998 & 0,676 & 0,525 & $-0,407$ & $-0,224$ & $-1,137$ & 0,281 & 0,919 & 0,316 & $-1,450$ & $-1,176$ \\
\hline 1999 & 0,602 & 0,467 & $-0,339$ & $-0,167$ & $-0,941$ & 0,422 & 0,915 & 0,254 & $-1,520$ & $-0,968$ \\
\hline 2000 & 0,446 & 0,509 & $-0,338$ & $-0,247$ & $-0,820$ & 0,338 & 1,056 & 0,297 & $-1,497$ & $-0,889$ \\
\hline 2001 & 0,026 & 0,481 & $-0,203$ & $-0,601$ & $-0,745$ & 0,348 & 0,928 & 0,423 & $-1,437$ & $-0,869$ \\
\hline 2002 & 0,542 & 0,559 & $-0,172$ & $-0,628$ & $-0,857$ & 0,278 & 0,966 & 0,463 & $-1,346$ & $-0,986$ \\
\hline 2003 & 0,764 & 0,547 & $-0,105$ & $-0,694$ & $-0,829$ & 0,256 & 1,056 & 0,564 & $-1,493$ & $-0,981$ \\
\hline \multirow[t]{3}{*}{2004} & 0,517 & 0,521 & 0,058 & $-0,695$ & $-0,859$ & 0,217 & 0,879 & 0,701 & $-1,341$ & $-0,955$ \\
\hline & \multicolumn{5}{|c|}{ TURKEY *POLAND } & \multicolumn{5}{|c|}{ TURKEY *ESTONIA } \\
\hline & $\mathbf{A}$ & $\mathbf{B}$ & C & D & $\mathbf{E}$ & $\mathbf{A}$ & B & C & D & $\mathbf{E}$ \\
\hline 1993 & $-0,088$ & 0,392 & $-0,038$ & $-0,383$ & $-0,945$ & 0,051 & 0,336 & 0,475 & $-1,309$ & $-0,256$ \\
\hline 1994 & $-0,037$ & 0,295 & $-0,063$ & $-0,395$ & $-0,824$ & 0,047 & 0,358 & 0,465 & $-1,353$ & $-0,164$ \\
\hline 1995 & $-0,046$ & 0,300 & $-0,055$ & $-0,5 \overline{07}$ & $-0,824$ & $-0,034$ & 0,387 & 0,375 & $-1,280$ & $-0,054$ \\
\hline 1996 & $-0,052$ & 0,260 & 0,039 & $-0,509$ & $-0,768$ & $-0,052$ & 0,314 & 0,482 & $-1,290$ & $-0,029$ \\
\hline 1997 & $-0,124$ & 0,260 & $-0,057$ & $-0,500$ & $-0,518$ & $-0,157$ & 0,505 & 0,379 & $-1,306$ & 0,070 \\
\hline 1998 & $-0,041$ & 0,296 & $-0,108$ & $-0,215$ & $-0,730$ & $-0,076$ & 0,493 & 0,509 & $-1,138$ & $-0,008$ \\
\hline
\end{tabular}




\begin{tabular}{|c|c|c|c|c|c|c|c|c|c|c|}
\hline \multicolumn{11}{|c|}{ Table 8: (continues) } \\
\hline & \multicolumn{5}{|c|}{ TURKEY *POLAND } & \multicolumn{5}{|c|}{ TURKEY *ESTONIA } \\
\hline & $\mathbf{A}$ & B & $\mathbf{C}$ & D & $\mathbf{E}$ & $\mathbf{A}$ & $\mathbf{B}$ & $\mathbf{C}$ & D & $\mathbf{E}$ \\
\hline 1999 & 0,004 & 0,260 & $-0,053$ & $-0,174$ & $-0,554$ & 0,040 & 0,401 & 0,596 & $-1,172$ & 0,204 \\
\hline 2000 & $-0,111$ & 0,329 & $-0,122$ & $-0,080$ & $-0,629$ & 0,071 & 0,546 & 0,653 & $-1,505$ & 0,291 \\
\hline 2001 & $-0,045$ & 0,293 & 0,097 & $-0,172$ & $-0,637$ & $-0,013$ & 0,336 & 0,828 & $-1,387$ & 0,249 \\
\hline 2002 & $-0,138$ & 0,303 & 0,115 & $-0,060$ & $-0,822$ & $-0,297$ & 0,274 & 0,702 & $-0,791$ & 0,016 \\
\hline 2003 & $-0,104$ & 0,290 & 0,131 & $-0,026$ & $-0,747$ & $-0,131$ & 0,311 & 0,513 & $-0,934$ & 0,027 \\
\hline 2004 & $-0,249$ & 0,288 & 0,121 & 0,075 & $-0,720$ & 0,160 & 0,199 & 0,833 & $-1,061$ & $-0,079$ \\
\hline
\end{tabular}

Source: Calculated from United Nations Statistics Division- (COMTRADE), SITC. Rev-3 data.

*A: Raw material-intensive goods, B: Labour-intensive goods, C: Capital- intensive goods, D: Easily imitable-research oriented goods, E: Difficultly imitable research-oriented goods. (See Appendix Table 1 for definition of each group)

Finally, although Turkey appears to be competitive in groups $\mathrm{B}$ and $\mathrm{C}$ against Estonia, our results are again not clear in groups $\mathrm{A}$ and $\mathrm{E}$. Estonia has a strong comparative advantage in group $\mathrm{D}$.

In sum, Table 8 indicates that Turkey has a clear comparative advantage in group B and comparative disadvantage in group D against all of four countries. Turkey's position is again disadvantageous in group $\mathrm{E}$ against all countries but Estonia.

In broad terms, country based RCA analysis suggests that Turkey has comparative disadvantage particularly in groups $\mathrm{D}$ and $\mathrm{E}$ which require high level of technology and investment. Turkey's main competitiveness against the four countries seems to be only in cases of labour intensive and low-tech industries. This result reveals the fact that Turkey actually has no comparative advantage in the industries generating relatively more value added. Therefore, in order to become more competitive in not only traditional but also high-tech industries against the four new members of EU, Turkey appears to be in a position to reconsider its industrial policies.

\section{Conclusion}

In theoretical part of this work, we first examine quite frequently used 'competitiveness' concept and different approaches towards defining it. We make it clear that though it is used by academics and other groups of society very often, competitiveness is a hard concept to define in an exact and unique way. Then we focus on the main theoretical and experimental problems in measuring and determining the key factors behind competitiveness.

In empirical part of the study, we provide a comparative analysis on macroeconomic performance, trade structure and competitiveness of Turkey 
and four new members of the EU, namely the Czech Republic, Hungary, Poland and Estonia. Two different most widely used competitiveness measures, comparative export performance (CEP) index and Balassa's revealed comparative advantage (RCA) indices, are employed to assess Turkey's competitiveness against the four new members in five commodity groups.

Our results initially indicate that the Czech Republic, Hungary, Poland and Turkey are comparable countries in terms of size of GDP and growth level. We also find that all of the new members were able to improve their trade relations with the EU since they began the full membership negotiations in the mid-1990s. Turkey and the EU also appear to be more important trade partners for each other, since implementation of the Customs Union Agreement in 1996.

These results just confirm that, after removal tariffs and other trade barriers between EU and the five countries, so called 'trade creation effect' of economic integration came into force in both trading partners. This is the expected outcome of reducing trade barriers between two or more countries and is one of the static effects of integration. However, there are also some dynamic effects, such as scale economies, technological improvements, promoting investment and increased mobility of production factors. As a result of all these process, today Turkey's trade with the EU constitutes more than half of total and this ratio reaches about 75 percent in the cases of the other four countries.

Analysis on relative competitiveness of countries suggests that Turkey has a comparative advantage against all of countries but Estonia in raw material, labour and partly capital intensive goods (groups A, B and C). However, Turkey appears to have a disadvantage in the products (groups D and $\mathrm{E}$ ) which require high technology and investment.

This finding implies that Turkey's comparative advantage with regard to the EU is partial and is only limited to some labour intensive industries, though there has been some improvements in export performance of medium and high tech industries particularly after the 2000s. It can be also argued that, accession of the four new members, together with previous ones (i.e. Greece, Portugal and, to some extent, Spain) which similarly have labour intensive factor endowments, is likely to put Turkey in even more difficult position in the future to compete with EU particularly in labour intensive industries. 
Given the fact that it is extremely hard for Turkey to improve its technology and investment level in the short run, a simple policy implication of this study is to promote foreign direct investment (FDI) which would both transfer new technologies and improve capital intensity. Through such increases in FDI, Turkey can able to export more researchoriented goods, leading better competitiveness levels in high technology requiring goods (groups D and E). Second policy proposal for Turkey is to give more attention on improving human capital and education level in the country as these would help export more capital intensive goods.

Finally, this study only attempts to assess Turkey's competitiveness against the new members of the EU at the sectoral level but the issue of determinants of Turkey's competitiveness is out of the scope of present work. Therefore, in order to establish a more detailed and effective trade policy for Turkey, determinants of Turkey's competitiveness (i.e. price and non-price factors) against the EU should also be taken into account in future studies.

\section{References:}

Akgüngör, S., Barbaros R. F. and Kumral N. (2002). Competitiveness of the Turkish Fruit and Vegetable Processing Industry in the Euroepan Union Market, Russian and East European Finance and Trade, 38(3), 34-53.

Atto, E.W. (1987). Relative Total Costs-An Approach to Competitiveness Measurement of Industries, Management International Review, 27(1), 47-58.

Balassa, B. (1965). Trade Liberalisation and 'Revealed' Comparative Advantage, The Manchester School of Economic and social Studies, 33(2), 99-123.

Ballence, R., Forstner, H. and Murray, T. (1985). On Measuring Comparative Advantage: A Note on Bowen's Indices, Weltwirtschaftliches Archiv, 121, 346-350.

Ballance, R., Forstner, H. and Murray, T. (1986). More on Measuring Comparative Advantage: A Reply, Weltwirtschaftliches Archiv, 122, 375-378. 
Bowen, H. P. (1983). On the Theoretical Interpretation of Indices of Trade Intensity and Revealed Comparative Advantage, Weltwirtschaftliches Archiv, 119, 464-472.

Bowen, H.P. (1985). On Measuring Comparative Advantage: A Reply and Extension, Weltwirtschaftliches Archiv, 121, 351-354.

Bowen, H.P. (1986). On Measuring Comparative Advantage: Further Comments, Weltwirtschaftliches Archiv, 122, 379-381.

Carlin, W., Glyn A. and Van Reenen J. (2001). Export Market Performance of OECD Countries: An Empirical Examination of the Role of Cost Competitiveness, The Economic Journal, 111(1), 128-162.

Cockburn, J., Siggel E., Coulibaly M. and Vezina S. (1998). 'Measuring Competitiveness and Its Sources: The Case of Mali's Manufacturing Sector', African Economic Policy Discussion Paper No. 16, United States Agency for International Development, Bureau of Africa, Washington, DC.

European Commission (1994). An Industrial Competitiveness Policy for the European Union, Bulletin of the European Union, Luxemburg: Office for Official Publications of the European Union.

European Commission (2004). External and Intra-European Union Trade Statistical Yearbook, Data 1958-2003, Luxembourg.

European Commission (2005). External and Intra-European Union Trade, Pocketbooks, Data 1999-2004, Luxembourg.

Ferman, M., Akgüngör, S. and Yüksel, A. H. (2004). 'Türkiye'nin İhracatı, Rekabet Gücü ve Sürdürülebilirliği', İktisat Kongresi Tebliğ Sunuşları: Gelişme Stratejileri ve Makroekonomik Politikalar, İzmir, DPT.

Francis, A. (1989). 'The Concepts of Competitiveness'. Francis A. and Tharakan P. K. M. (eds.), The Competitiveness of European Industry: Country Policies and Company Strategies, London-New York: Routledge.

Heidensohn, K. and Hibbert, E. P. (1997). A Sectoral Analysis of Europe's International Competitiveness, Competitiveness Review, 7(2), 25-37.

Hillman, A. L. (1980). Observations on The Relation Between 'Revealed Comparative Advantage' and Comparative Advantage as Indicated by Pre-trade Relative Prices, Weltwirtschaftliches Archiv, 116, 315-321. 
Hirsch, S. (1967). Location of Industry and International Competitiveness, Oxford: Clarendon.

Hufbauer, G. C. and Chilas, J. C. (1974). 'Specialization by Industrial Countries: Extent and Consequence'. Giersch, H. and J. C. B., Mohr (Paul Siebeck) (eds.), The International Division of Labour: Problems and Perspectives, International Symposium, Tübingen, Germany.

IMD-International Institute for Management Development (2005). The World Competitiveness Scoreboard 2005. Retrieved: March 14, 2006, from http://www01.imd.ch/documents/wcc/content/overallgraph.pdf>

Jakab, Z. M., Kovacs, M. A. and Oszlay, A. (2001). How Far Has Trade Integration Advanced?: An Analysis of the Actual and Potential Trade of Three Central and Eastern European Countries, Journal of Comparative Economics, 29, 276-292.

Karakaya, E. and Özgen, F. B. (2002). 'Economic Feasibility of Turkey's Economic Integration with the EU: Perspectives from Trade Creation and Trade Diversion'. METU 6. International Economics Congress, Ankara.

Küçükahmetoğlu, O. (1996). "Gümrük Birliği ve Turkey'nin Rekabet Gücü", Gümrük Dergisi, November, Special Edition on Customs Union and Turkey, 34-47.

Lafay, G. (1992). 'The Measurement of Revealed Comparative Advantages', Dagenais, M. G. and Muet, P. A. (eds.), International Trade Modelling, London: Chapman\&Hall.

Lankhuizen, M. (2000). Shifts in Foreign Trade, Competitiveness and Growth Potential: From Baltics to 'Bal-techs'?, Research Policy, 29, 929.

Lee, J. (1995). Comparative Advantage in Manufacturing as a Determinant of Industrialization: The Korean Case, World Development, 23(7), 11951214.

Martin, L., Westgren, R. and Van Duren, E. (1991). Agribusiness Competitiveness Across National Boundaries, American Journal of Agricultural Economics, 73(5), 1456-1464.

Nilsson, L. (2000). Trade Integration and the EU Economic Membership Criteria, European Journal of Political Economy, 16, 807-827. 
Porter, M. (1990). The Competitive Advantages of Nations, New York: The Free Press.

Rodas-Martini, P. (1998). Intra-Industry Trade and Revealed Comparat ive Advantage in the Central American Common Market, World Development, 26(2), 337-344.

Soğuk, H. and Uyanusta, E. (2004). Gümrük Birliği'nin Türkiye Ekonomisine Etkileri, İktisadi Kalkınma Vakfı Yayınları,No: 179, İstanbul, 11-14.

TUIK (2006). GDP in $4^{\text {th }}$ quarter of 2005. Retrieved: February 25, 2006, from http://www.die.gov.tr/TURKISH/SONIST/GSMH/k_310306.xls

United Nations Statistics Division-Commodity Trade Statistics Database (COMTRADE), SITC. Rev-3. Retrieved: January 07, 2006, from http://unstats.un.org

WEF-World Economic Forum (2004). Growth Competitiveness Index Rankings and 2003 Comparison. Retrieved: January 15, 2006, from http://www.weforum.org/pdf/Gcr/Growth_Competitiveness_Index_2003 _Comparisons

WORLD BANK (2005). World Development Indicators. Retrieved: February 08, 2006, from http://devdata.worldbank.org/data-query/

WORLD TRADE ORGANIZATION (2004). International Trade Statistics 2004. Retrieved: January 25,2006 , from http://www.wto.org/english/res_e/statis_e/its2004_e/its2004_e.pdf

Wu, H.L. and Chen, C.H. (2004). Changes in the Foreign Market Competitiveness of East Asian Exports, Journal of Contemporary Asia, 34(4), 503-522.

Yeats, A. J. (1985). On The Appropriate Interpretation of the Revealed Comparative Advantage Index: Implications of a Methodology Based Industry Sector Analysis, Weltwirtschaftliches Archiv, 121, 61-73.

Yetkin, M. N. (1998). Türkiye-AB İlişkilerinin Tarihsel Gelişimi ve Değerlendirilmesi, Dış Ticaret Dergisi, Special Edition, October, 89-90.

Yllmaz, B. (2002). Turkey's Competitiveness in the European Union, Russian and East European Finance and Trade, 38(3), 54-72.

Yllmaz, B. (2003). Turkey's Competitiveness in the European Union: A Comparison with Five Candidate Countries-Bulgaria, The Czech Republic, Hungary, Poland, Romania - And The EU15, Ezoneplus 
Working Paper, No.12, February. Retrieved: September 19, 2005, from www.ezoneplus.org

Y1lmaz, B. and Ergun, S. (2003). The Foreign Trade pattern and Foreign Trade Specialization of Candidates of the European Union, Ezoneplus Working Paper, No. 19, September. Retrieved: October 24, 2005, from www.ezoneplus.org

Yue, C. and Hua, P. (2002). Does Comparative Advantage Explains Export Patterns in China, China Economic Review, 13(2), 279-296.

\section{Appendix TABLE 1:}

\section{SITC CLASSIFICATION}

\begin{tabular}{|l|l|}
\hline Commodity Group & SITC Rev.3 Codes \\
\hline Raw material-intensive goods. & SITC $0 ; 2-26 ; 3-35 ; 4 ; 56$ \\
\hline Labour-intensive goods. & SITC $26 ; 6-62,67,68 ; 8-87,88$ \\
\hline Capital- intensive goods. & SITC $1 ; 35 ; 53 ; 55 ; 62 ; 67 ; 68 ; 78$ \\
\hline Easily imitable-research oriented goods. & SITC $51 ; 52 ; 54 ; 58 ; 59 ; 75 ; 76$ \\
\hline $\begin{array}{l}\text { Difficultly imitable research-oriented } \\
\text { goods. }\end{array}$ & SITC $57 ; 7-75,76,78 ; 87 ; 88$ \\
\hline
\end{tabular}

Source: Hufbauer and Chilas (1974). 